\title{
Ranking of Bioresources for Biogas Production
}

\author{
Ketija BUMBIERE $^{*}$, Agita GANCONE${ }^{2}$, Jelena PUBULE ${ }^{3}$, Vladimirs KIRSANOVS ${ }^{4}$, \\ Saulius VASAREVICIUS ${ }^{5}$, Dagnija BLUMBERGA ${ }^{6}$ \\ 1-4, ${ }^{6}$ Institute of Energy Systems and Environment, Riga Technical University, Azenes iela 12/1, Riga, \\ LV-1048, Latvia \\ ${ }^{5}$ Faculty of Environmental Protection, Vilnius Gediminas Technical University, Sauletekio al. 11, Vilnius \\ 10221, Lithuania
}

\begin{abstract}
Production of biogas using bioresources of agricultural origin plays an important role in Europe's energy transition to sustainability and to a climate-neutral economy. The usage of some substrates like maize has been increasingly denounced in the last years and there is currently an active discussion about future subsidies to biogas producers depending on the substrate used. The aim of this study is to compare and rank different substrates for biogas production considering their economic feasibility, substrate efficiency and environmental aspects. During the research, eight substrates were evaluated: cattle manure, pig manure, poultry manure, straw, wood, maize silage, waste, and sewage sludge. In order to reach the research goal, multi-criteria analysis using TOPSIS methodology was applied to objectively determine which of the substrates considered would be the most suitable for biogas production in Latvia. The results obtained showed that pig manure is the most suitable raw material for biogas production in Latvia, while poultry manure was ranked second, with little difference in value from pig manure.
\end{abstract}

Keywords - Biogas; economic feasibility; maize; manure; substrate efficiency; TOPSIS.

\section{INTRODUCTION}

Production of biogas using bioresources of agricultural origin plays an important role in Europe's energy transition to sustainability and a climate-neutral economy [1]-[3]. The transition to clean energy has already proven its worth by modernizing the EU's economy, promoting sustainable economic growth and prosperity, as well as improving the environment, creating new jobs and delivering benefits for citizens [4]. Given that around 6 million tons of agricultural waste is produced in the world yearly and the emphasis on pathways and strategic priorities for transition to a net-zero GHG emission economy, there is a promising future for the development of biogas production, especially for upgraded biogas to biomethane, which is flexible both in use and storage and because its production from agricultural, industrial waste and sewage sludge protects soil, air and water from pollution [5], [6]. Not only does biogas produced by anaerobic digestion prevent greenhouse gas emissions and produce renewable energy from waste, but also provides for the production of processed fertilizers, improving nutrient self-sufficiency in the agricultural sector [7].

The biogas production process is an environmental technology that integrates production [8], processing and recycling of degradable by-products [9]. In 2014 there were 54 first- and secondgeneration biogas plants [10] operating in Latvia with a total capacity of $54.92 \mathrm{MW}$ (3.1 PJ) and

* Corresponding author.

E-mail address: ketija.bumbiere@rtu.lv 
out of those 54 biogas plants, 44 used agricultural waste, 7 used municipal waste in landfills, but only 3 used domestic or industrial sewage and residues from food production (industrial waste) [11]. Consumption of biogas produced in 2017 increased to $80.73 \mathrm{MW}$ (3.9 PJ) since 2014, reaching a $25.81 \%$ increase of biogas production [12].

The productivity of a biogas plant depends on different aspects, like type of biomass [13], digestion [14], availability of biomass, impurities that may harm microorganisms [15] and lignin content [16].

Different types of manure present variation in organic composition and dry matter content (1.5$30.0 \%$ ), which affects the biogas produced. Co-digestion is often used for the very reason that the optimal carbon-nitrogen ratio on biogas production is in the rage of 20:1 to 30:1, but in general, manure has very low carbon ratio and it is important to mix it with other substrates that are carbonrich to increase the biogas yield [14], [17].

TABLE 1. Yield OF VARIOUS RAW MATERIALS [18]

\begin{tabular}{lll}
\hline & Yield of methane, $\%$ & Yield of biogas, $\mathbf{~ m}^{\mathbf{3}} \mathbf{/ t}$ \\
\hline Cattle manure (liquid) & 60 & 25 \\
Cattle manure & 60 & 45 \\
Pig manure (liquid) & 65 & 28 \\
Pig manure & 60 & 60 \\
Poultry manure & 60 & 80 \\
Maize silage & 52 & 202 \\
Grass silage & 52 & 172 \\
Organic waste & 61 & 100 \\
\hline
\end{tabular}

The most commonly used substrate with manure for co-digestion is maize silage. The yield of different raw materials is shown in Table 1. Comparing the biogas yield of maize silage with the biogas yield of liquid cattle manure, the biogas yield from maize silage is 8,08 times higher [19].

The use of lignocellulosic substrates after pre-treatment [20] for biogas production should be evaluated. Given that the use of maize and rapeseed silage in biogas production will no longer be acceptable, it is necessary to find new raw materials that occurs as a result of other processes as waste. Considering that a half of Latvia's territory is covered by forests in 2016, and $36.5 \%$ of Latvia's territory is covered by agricultural lands, Latvia has a big potential to use harvesting and agricultural crop residues and waste, which have high levels of lignin in their content [21].

Grasslands have a variety of functions in agriculture - not only are they primarily the main source of feed for livestock, but overall, they provide benefits such as carbon storage and soil protection from erosion, groundwater formation and habitat formation in diverse landscapes and natural foundations [22]. Although grasslands can be used in the production of lignocellulosic bioethanol, synthetic natural gas or synthetic biofuels, according to the Green Biorefineries concept, the sustainable use of grass biomass is directly linked to the production of biogas [22]. Knowing the feasibility of successful processing of such raw materials and their practical application, it is understandable that they are potential raw materials also in the agricultural conditions of Latvia.

Anaerobic digestion has been mainly implemented for the management of animal manure, organic and agricultural waste, sewage sludge, plant green mass etc. [23]. Theoretically it is possible to use forest and wood processing waste and peat [24]. 
Manure is the most suitable material for biogas production. The easiest way to get biogas is from cattle manure. The dry matter content of the manure depends on the used amount of litter, moreover if a lot of washing water is used, the manure is watery [25].

Pig manure is also very suitable for biogas production, because it contains not only manure, but also feed residue and litter. Bird manure is very suitable for biogas production also, but there tends to be sand and feathers mixed in the manure, which can cause problems, when specially adopted pumps are not used. Because of the high concentration of nitrogen, it is advisable to mix poultry manure with cattle manure [24].

\section{METHOdOLOGY}

Multi-criteria analysis was carried out to determine Latvia's biogas sector potential - to predict the best feedstock depending on resources available in the country, which of the substrates for biogas production has the highest potential and sustainability. The following raw materials were analysed in this multi-criteria analysis: cattle manure, pig manure, poultry manure, sewage sludge, organic waste, wood, straw, maize silage.

The year 2017 was used for data collection, and multi-criteria analysis does not take into account the size of the farms, which is related to the actual number of livestock, manure collection technology and the transportation distance from the raw material extraction site to the biogas plant.

For the purpose of multicriteria analysis, the efficiency of different feedstocks in terms of yield, were how many cubic meters of biogas can be obtained from a ton of a given feedstock was analysed. The efficiency of raw materials was determined as an average value [26]-[28].

In order to determine the importance of using a particular substrate in the production of biogas, data was collected on how many emissions could be eliminated altogether, thus approximating the proportion of their availability and importance, and environmental impact depending on how much this material is produced in one year and its emission factor. To calculate objectively the amount of emissions that could potentially be avoided (both nitrous oxide and methane), emissions were compared to carbon dioxide equivalents and added up. $1 \mathrm{~kg}$ of nitrous oxide was calculated as $298 \mathrm{~kg}$ carbon dioxide, while $1 \mathrm{~kg}$ of methane was calculated as $25 \mathrm{~kg}$ carbon dioxide [28].

In total three main criteria were considered: substrate efficiency, environmental friendliness, and economic feasibility.

TABLE 2. CHARACTERISTICS OF LIVESTOCK NUMBERS AND EMISSIONS FROM MANURE MANAGEMENT IN 2017 [29]

\begin{tabular}{llllll}
\hline & $\begin{array}{l}\text { Mature dairy } \\
\text { cattle }\end{array}$ & $\begin{array}{l}\text { Other } \\
\text { mature cattle }\end{array}$ & $\begin{array}{l}\text { Growing } \\
\text { cattle }\end{array}$ & Pig & Poultry \\
\hline Population size, thousands & 150.4 & 77.5 & 177.9 & 320.6 & 4943.8 \\
$\mathbf{C H}_{\mathbf{4}}$ emissions, kt & 2.60 & 0.15 & 0.20 & 0.79 & 0.07 \\
$\mathbf{C H}_{\mathbf{4}}$ emissions, kt $\mathbf{C O}_{\mathbf{2}}$ equivalent & 65.00 & 3.75 & 5.00 & 19.75 & 1.75 \\
$\mathbf{N}_{\mathbf{2}} \mathbf{O}$ emissions, kt & 0.11 & 0.01 & 0.02 & 0.02 & 0.01 \\
$\mathbf{N}_{\mathbf{2}} \mathbf{O}$ emissions, kt $\mathbf{C O}_{2}$ equivalent & 32.78 & 2.98 & 5.96 & 5.96 & 2.98 \\
Emissions in total, kt $\mathbf{C O}_{2}$ equivalent & 97.78 & 6.73 & 10.96 & 25.71 & 4.73 \\
\hline
\end{tabular}

In order to determine, which is the most important criteria, a survey and a vote was carried out among different experts in the field of biogas production. As a result, of the $100 \%$ experts voted that the most important criteria was climate friendliness with $35 \%$ as the deciding 
factor. Only $5 \%$ less important was the technological aspect responsible for substrate efficiency. The economic justification for this sector's priorities and comparison with the other two criteria was determined as the last one with $35 \%$.

In order to objectively determine the potential of manure for biogas production, a summary was made, which is shown in Table 2, to summarize the amount of specific livestock manure and emissions in Latvia in one year.

Since the information about livestock population and emissions for 2017 is available, it is used for the analysis. Table 2 shows that although poultry has the highest numbers, methane emissions from cattle are the highest and to use them for biogas production would be more significant, if only by looking at annual emissions, because altogether cattle emissions reach $115.47 \mathrm{kt} /$ year, but pig manure is also a very important resource, although the number of pigs is $21 \%$ lower, the emissions emitted are still significant.

Domestic and industrial wastewater emissions are calculated and showed in Table 3.

TABLE 3. WASTEWATER DRY CONTENT AND EMISSIONS IN 2017 [29]

\begin{tabular}{|c|c|c|c|c|c|c|}
\hline & $\begin{array}{l}\text { Total } \\
\text { organic } \\
\text { product, } \\
\text { kt DC/year }\end{array}$ & $\begin{array}{l}\mathrm{CH}_{4} \\
\text { emissions, } \\
\mathrm{kt}\end{array}$ & $\begin{array}{l}\mathrm{CH}_{4} \text { emissions } \\
\text { as } \mathrm{CO}_{2} \\
\text { equivalent, kt }\end{array}$ & $\begin{array}{l}\mathrm{N}_{2} \mathrm{O} \\
\text { emissions, kt }\end{array}$ & $\begin{array}{l}\mathrm{N}_{2} \text { Oemissions } \\
\text { as } \mathrm{CO}_{2} \\
\text { equivalent, } \mathrm{kt}\end{array}$ & $\begin{array}{l}\text { In total, } \\
\text { kt } \mathrm{CO}_{2} \\
\text { equivalent }\end{array}$ \\
\hline $\begin{array}{l}\text { Domestic } \\
\text { wastewater }\end{array}$ & 42.71 & 3.16 & 79.00 & 0.11 & 32.78 & 111.78 \\
\hline $\begin{array}{l}\text { Industrial } \\
\text { wastewater }\end{array}$ & 13.51 & 0.07 & 1.75 & 0.00 & 0.00 & 1.75 \\
\hline
\end{tabular}

Methane emissions from solid waste are shown in Table 4. In total both managed and unmanaged waste disposal sites emit $403.50 \mathrm{kt} \mathrm{CO}_{2}$ equivalent per year, because of the organic waste in disposal sites. This problem could be partly overcome by changing the shopping and eating habits of people, thus reducing the amount of food thrown away. However, such a shift in people's behaviour takes a long time and, until it is successful, this "waste" can be used effectively in biogas production because it is creating the biggest emissions of all analysed raw materials in this research.

Table 4. Annual Solid Waste Emissions in 2017 AT the Waste Disposal Sites [29]

\begin{tabular}{llll}
\hline & Annual waste, kt & $\mathbf{C H}_{\mathbf{4}}$ emissions, kt & $\begin{array}{l}\mathbf{C H}_{\mathbf{4}} \text { emissions, kt } \mathbf{C O}_{2} \\
\text { equivalent }\end{array}$ \\
\hline Managed waste disposal sites & 230.62 & 10.55 & 263.75 \\
Unmanaged waste disposal sites & - & 5.59 & 139.75 \\
\hline
\end{tabular}

\section{RESUlts}

In order to determine, which feedstock is the most economically advantageous for biogas production, information on feedstock prices was collected. The largest advertisement portal in Latvia www.ss.com was used to find out the price of manure, as well as straw and corn, which showed that, on average, cattle manure is sold for $3 € / t$, poultry manure for $2 € / t$, but pig manure is charged a very symbolic price of about $1 € / t$ [30]. Straw bales were found to weigh an average of $0.45 \mathrm{t}$, but 1 bale is sold for an average of $7 € /$ piece, while $1 \mathrm{t}$ of corn silage costs $50 €[30]$. By making the calculations, $1 \mathrm{t}$ of straw costs $15.56 € / \mathrm{t}$. A symbolic price of $1 € / t$ was adopted for wastewater sludge. The price of organic waste was determined 
by obtaining information on the website of the largest landfill site in Latvia, where it is offered to deliver the organic waste to landfill for $60.81 € / \mathrm{t}+\mathrm{VAT}$. It means that the cost of transferring the waste in total with VAT costs is $73.58 € / t$ [31]. As the transfer of this waste costs a certain amount of money, its use at the on-farm biogas plant means a reduction in costs and for that reason the cost of organic waste is shown with a minus sign in Table 5 . According to surveys of the biggest woodchip suppliers, its price is currently $12 € / \mathrm{m}^{3}$. Given that $1 \mathrm{t}$ of woodchips is equivalent to $3.5 \mathrm{~m}^{3}$ of woodchips, the price per $\mathrm{t}$ is assumed to be $42 €$.

Summarizing the information obtained on the biogas efficiency of the particular feedstocks as well as the price per $t$ of the feedstock, it is possible to obtain an economic justific ation for each substrate. To obtain the cost of producing $1 \mathrm{~m}^{3}$ of biogas from a given substrate, the substrate price was divided by the substrate efficiency.

TABle 5. CAlCUlation of ECONOMiC JustificAtion fOR EACH SubSTRATE

\begin{tabular}{llll}
\hline & $\begin{array}{l}\text { Effectivity, yield of } \\
\text { biogas, } \mathbf{~ m}^{\mathbf{3} / \mathbf{t}}\end{array}$ & Price of the feedstock, $\boldsymbol{\epsilon} / \mathbf{t}$ & $\begin{array}{l}\text { Economically justified, } \\
\boldsymbol{\epsilon} / \mathbf{m}^{\mathbf{3}} \text { biogas }\end{array}$ \\
\hline Cattle manure & 35 & 3.00 & 0.09 \\
Pig manure & 44 & 1.00 & 0.02 \\
Poultry manure & 80 & 2.00 & 0.03 \\
Sewage sludge & 218 & 1.00 & 0.01 \\
Organic waste & 100 & -73.58 & -0.74 \\
Wood & 35.5 & 42.00 & 1.18 \\
Straw & 190 & 15.56 & 0.08 \\
Maize silage & 202 & 45.00 & 0.25 \\
\hline
\end{tabular}

As a result, the three main criteria identified as determinants of biogas substrate selection were summarized in Table 6 for objective comparison.

TABle 6. Multi-Criteria AnAlysis VAlues

\begin{tabular}{llll}
\hline & $\begin{array}{l}\text { Effective } \\
\left.\text { (yield of biogas, } \mathbf{~ m}^{\mathbf{3}} / \mathbf{t}\right)\end{array}$ & $\begin{array}{l}\text { Environmentally friendly } \\
\text { (emissions to be collected in Latvia, }, \\
\left.\mathbf{k t ~} \mathbf{C O}_{\mathbf{2}} \mathbf{~ e q} / \mathbf{y e a r}\right)\end{array}$ & $\begin{array}{l}\text { Economically } \\
\text { justified } \\
\left(\boldsymbol{\epsilon} / \mathbf{m}^{\mathbf{3}} \mathbf{\text { biogas} )}\right.\end{array}$ \\
\hline Cattle manure & 35.0 & 115.47 & 0.09 \\
Pig manure & 44.0 & 25.71 & 0.02 \\
Poultry manure & 80.0 & 4.73 & 0.03 \\
Sewage sludge & 218.0 & 113.53 & 0.01 \\
Organic waste & 100.0 & 403.50 & -0.74 \\
Wood & 35.5 & 0.00 & 1.18 \\
Straw & 190.0 & 0.00 & 0.08 \\
Maize silage & 202.0 & -6.56 & 0.25 \\
\hline
\end{tabular}

After gathering information about the substrates, it can be seen that the highest efficiency of biogas production is in the production of biogas from sewage sludge as well as maize silage. Straw does not lag behind in the productivity of maize silage biogas. The lowest efficiency is observed in cattle manure and wood, with average efficiency values almost equal. Only slightly higher efficiency is observed in pig manure. 
Considering which raw material should preferably be selected for the most environmentally friendly production of biogas, it appears that the most airborne emissions can be prevented by anaerobic fermentation of organic waste. The use of sewage sludge for biogas production as well as the use of cattle manure would provide about 3.4 times less, but still significant emission savings. Equally important is the use of pig manure, but their total methane emissions are lower due to pig numbers. It is also very important to use poultry manure, as their biogas efficiency is only $20 \%$ lower than the efficiency of solid waste, but their environmental impact is less significant due to the quantitative value of this manure. The emissions from biogas maize production in Latvia is the only substrate considered here that generates emissions rather than being neutral.

Economically, the most detrimental raw material for biogas production is wood, if purchased as wood chips, but the most advantageous is the use of organic waste, as it not only allows biogas to be produced, but also helps to reduce the cost of waste transfer to landfills.

In order to determine objectively the best raw material for biogas production, the TOPSIS model was developed.

After the TOPSIS methodology calculations were made, a rating was obtained of which, according to the accepted three criteria (environment, technology, economic), indicates where the given substrate is ranked from the most suitable substrate for biogas production in Latvia ranked first to the worst substrate from this list, ranked in the last $8^{\text {th }}$ place.

Pig and poultry manure were ranked in the first two places according to the criteria, while straw with pre-treatment was ranked $3^{\text {rd }}$; cattle manure was ranked $4^{\text {th }}$, and sewage sludge ranked $5^{\text {th }}$. The last three places are organic waste, corn and wood, which took a convincing last place in the ranking.

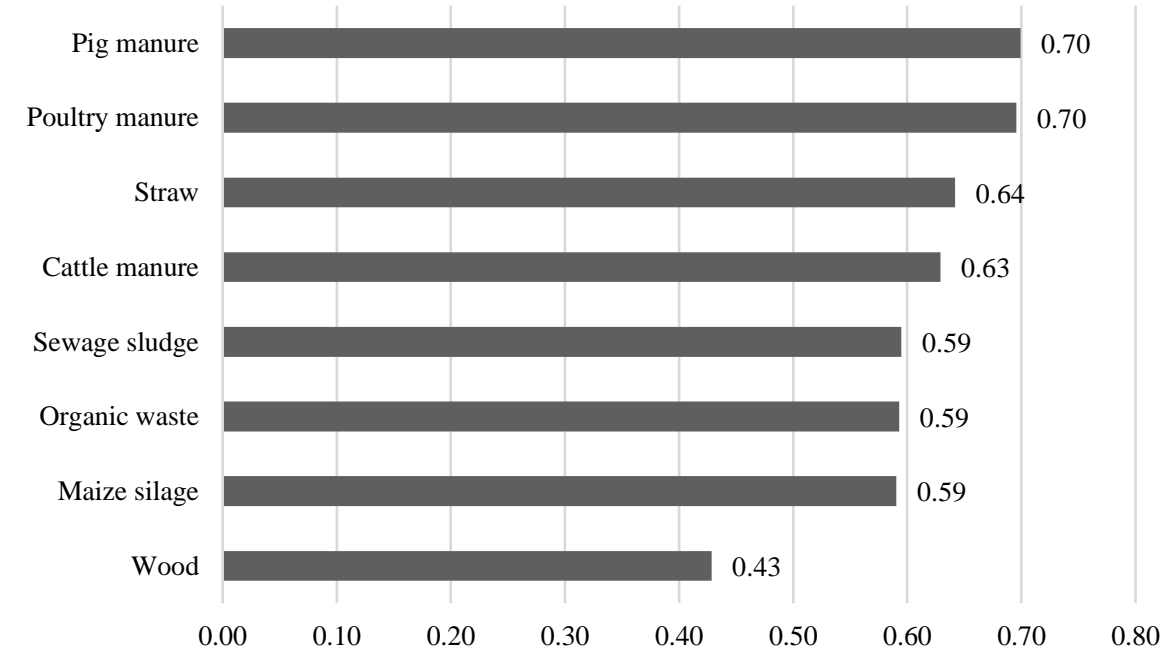

Fig. 1. Relative closeness to the ideal solution with TOPSIS method.

Fig. 1 shows that the raw materials are basically divided into four groups according to the suitability of the substrate for biogas production:

- Group with convincing highest relative closeness to the ideal solution with TOPSIS method, which includes pig and poultry manure and have very similar values;

- Group with the second highest relative closeness to the ideal solution with TOPSIS 
method, which includes straw and cattle manure and have very small difference in values between them;

- Group which includes sewage sludge, organic waste and maize silage - feedstocks, the numerical value of which in terms of relative closeness to the ideal solution is nearly the same;

- Group which consists with the worst feedstock among the ones considered for the particular biogas production method is wood.

\section{Conclusions}

A multi-criteria analysis using TOPSIS methodology and taking into account three main parameters: economic feasibility, substrate efficiency, and environmental aspects, showed that pig manure is the most suitable raw material for biogas production in Latvia, while poultry manure was ranked second, with very little difference in value from pig manure.

Despite the claim that lignocellulose rich plants are not a successful choice for biogas production, straw was the third best substrate for biogas production in Latvia, and cattle manure was in $4^{\text {th }}$ place. Wood was identified as the most unsuccessful choice for biogas feedstock.

The penultimate place in the ranking was for specially grown maize for biogas production, which until now has been a popular substrate for agricultural biogas production.

Based on the criteria used in the model, the organic waste and sewage sludge are roughly the same as biogas maize in the rating. This work proves that pre-treatment straw can serve as a great substitute for biogas maize.

The use of any waste for energy production is important, but the greatest potential shows in agricultural biogas from manure and straw.

\section{ACKNOWLEDGEMENT}

The research is funded by the Ministry of Economics of the Republic of Latvia, project "Sustainable and renewable transport policy formulation in Latvia (4muLATe)", project No. VPP-EM-2018/AER-2-0003.

\section{REFERENCES}

[1] European Commission. Communication from the Commission to the European Parliament, the Council, the European Economic and Social Committee and the Committee of the regions. A policy framework for Climate and Energy in the period from 2020 to 2030, 2014. [Online]. [Accessed 15.05.2015]. Available: https://ec.europa.eu/clima/policies/strategies/2030_en.

[2] European Commission. 2050 long-term strategy. Going climate-neutral by 2050, 2018. [Online]. [Accessed 15.05.2015]. https://ec.europa.eu/clima/policies/strategies/2050_en

[3] Bereiter B., Eggleston S., Schmitt J., Nehrbass-Ahles C., Stocker T. F., Fischer H., Kipfstuhl S., Chappellaz J. Revision of the EPICA Dome $\mathrm{C} \mathrm{CO}_{2}$ record from 800 to $600 \mathrm{kyr}$ before present. Geophysical Research Letters 2015:42(2):542549. https://doi.org/10.1002/2014GL061957

[4] European Commission. Communication from the Commission to the European parliament, the European council, the council, the European economic and social committee, the committee of the regions and the European investment bank. A Clean Planet for all A European strategic long-term vision for a prosperous, modern, competitive and climate neutral economy, 2018. [Online]. [Accessed 15.05.2015] https://eur-lex.europa.eu/legalcontent/EN/TXT/?uri=CELEX:52018DC0773.

[5] Scarlat N., Dallemand J. F., Fahl F. Biogas: Developments and perspectives in Europe. Renewable Energy 2018:129 (A):457-472. https://doi.org/10.1016/j.renene.2018.03.006

[6] Yu Q., Liu R., Li K., Ma R. A review of crop straw pretreatment methods for biogas production by anaerobic digestion in China. Renewable and Sustainable Energy Reviews 2019:107:51-58. https://doi.org/10.1016/j.rser.2019.02.020 
[7] Timonen K., Sinkko T., Luostarinen S., Tampio E., Joensuu K. LCA of anaerobic digestion: Emission allocation for energy and digestate. Journal of Cleaner Production 2019:235:1567-1579. https://doi.org/10.1016/j.jclepro.2019.06.085

[8] Chen X. Y., Vinh-Thang H., Ramirez A. A., Rodrigue D., Kaliaguine S.. Membrane gas separation technologies for biogas upgrading. RSC Advances 2015:5:31:24399-24448. https://doi.org/10.1039/C5RA00666J

[9] Karklins A. Biogas production in Latvia. Possibilities of obaining and using biomethane [Online]. [Accessed 15.05.2015]. http://www.sam.gov.lv/images/modules/items/PDF/item_6133_6_LBA_biometans_SM_06.2016.pdf.

[10] BiogasAction - New developments in Latvia. [Online]. [Accessed 15.05.2015]. https://www.fedarene.org/biogasaction-new-developments-latvia-23060.

[11] Development of biogas in Latvia [Online]. [Accessed 15.05.2015]. http://latvijasbiogaze.lv/index.php?c=3.

[12] Central Statistical Bureau of Latvia. Renewable energy consumption in 2017 [Online]. [Accessed 15.05.2015]. https://www.csb.gov.lv/lv/statistika/statistikas-temas/vide-energetika/energetika/meklet-tema/2407-atjaunigoenergoresursu-paterins-2017-gada.

[13] Meyer A. K. P., Ehimen E. A., Holm-Nielsen J. B. Future European biogas: Animal manure, straw and grass potentials for a sustainable European biogas production. Biomass and Bioenergy 2018:111:154-164. https://doi.org/10.1016/j.biombioe.2017.05.013

[14] Mano Esteves E. M., Naranjo Herrera A. M., Peçanha Esteves V. P., Morgado C. R. V. Life cycle assessment of manure biogas production: A review. Journal of Cleaner Production 219:411-423. https://doi.org/10.1016/j.jclepro.2019.02.091

[15] Muizniece I., Zihare L., Pubule J., Blumberga D. Circular Economy and Bioeconomy Interaction Development as Future for Rural Regions. Case Study of Aizkraukle Region in Latvia. Environmental and Climate Technologies 2019:23(3):129-146. https://doi.org/10.2478/rtuect-2019-0084

[16] Lauka D., Slisane D., Ievina L., Muizniece I., Blumberga D. When Bioeconomy Development Becomes a Biomass Energy Competitor. Environmental and Climate Technologies 2019:23(3):347-359. https://doi.org/10.2478/rtuect2019-0100.

[17] Conti F., Saidi A., Goldbrunner M., CFD Modelling of Biomass Mixing in Anaerobic Digesters of Biogas Plants. Environmental and Climate Technologies 2019:23(3):57-69. https://doi.org/10.2478/rtuect-2019-0079

[18] Blumberga, D., Veidenbergs, I., Romagnoli, F., Rochas, C., Žandeckis, A. Bioenergy Technologies, Riga: RTU, 2011.

[19] European Environmental Agency. EMEP/EEA air pollutant emission inventory guidebook 2019. Biological treatment of waste - anaerobic digestion at biogas facilities [Online]. [Accessed 15.05.2015]. Available: file:///C:/Users/jelen/Downloads/5.B.2\%20Biological\%20treatment\%20of\%20waste\%20$\% 20$ anaerobic\%20Digestion\%20Biogas\%202019.pdf.

[20] Li K., Liu R., Sun C. A review of methane production from agricultural residues in China. Renewable and Sustainable Energy Reviews 2016:54:857-865. https://doi.org/10.1016/j.rser.2015.10.103

[21] Ministry of Environment and Regional development of Latvia. Land policy plan for 2016-2020. [Online]. [Accessed 15.05.2015]. (in Latvian)

http://www.varam.gov.lv/in site/tools/download.php?file=files/text/Sab_lidzdaliba/sab_apsp/VARAM Zemes politi kas_plans_211116.pdf

[22] Prochnow A., Heiermann M., Plöchl M., Linke B., Idler C., Amon T., Hobbs P. J. Bioenergy from permanent grassland - A review: 1. Biogas. Bioresource Technology 2009:100:21:4931-4944. https://doi.org/10.1016/j.biortech.2009.05.070

[23] Chiumenti A., Borso F., Limina S. Dry anaerobic digestion of cow manure and agricultural products in a full-scale plant: Efficiency and comparison with wet fermentation. Waste Management 2018:71:704-710. https://doi.org/10.1016/j.wasman.2017.03.046

[24] Latvian Renewable Energy federation. Biogas energy [Online]. [Accessed 15.05.2015]. Available: https://www.laef.lv/en/biogas//

[25] Putri D., Saputro R., Budiyono B. Biogas Production from Cow Manure. International Journal of Renewable Energy Development 2012:1:2:61-64. https://doi.org/10.14710/ijred.1.2.61-64

[26] Berglund Odhner P., Sárvári Horváth I., H. Mohseni Kabir M., Schabbauer A. Biogas from lignocellulosic biomass, 2012 [Online]. [Accessed 15.05.2015]. http://www.sgc.se/ckfinder/userfiles/files/SGC247.pdf.

[27] Tong H., Tong Y. W., Peng Y. H. A comparative life cycle assessment on mono- and co-digestion of food waste and sewage sludge. Energy Procedia 2019:158:4166-4171. https://doi.org/10.1016/j.egypro.2019.01.814

[28] Climate Change Connection. $\mathrm{CO}_{2}$ equivalents [Online]. [Accessed 15.05.2015]. Available: https://climatechangeconnection.org/emissions/co2-equivalents/

[29] Brēmere I., Indriksone D., Klāvs G., Reḳis J. Synergies and Conflicting Impacts of GHG Reduction Measures Recommendation Report. 2016 [Online]. [Accessed 15.05.2015]. Available: https://www.bef.lv/wpcontent/uploads/2018/03/Rekomendacijas_zinojums_BEF.pdf

[30] Advertisements [Online]. [Accessed 15.05.2015]. Available: www.ss.com https://www.ss.com/

[31] Tariffs for municipal waste [Online]. [Accessed 15.05.2015]. Available: http://www.getlini.lv/en/private-clients 

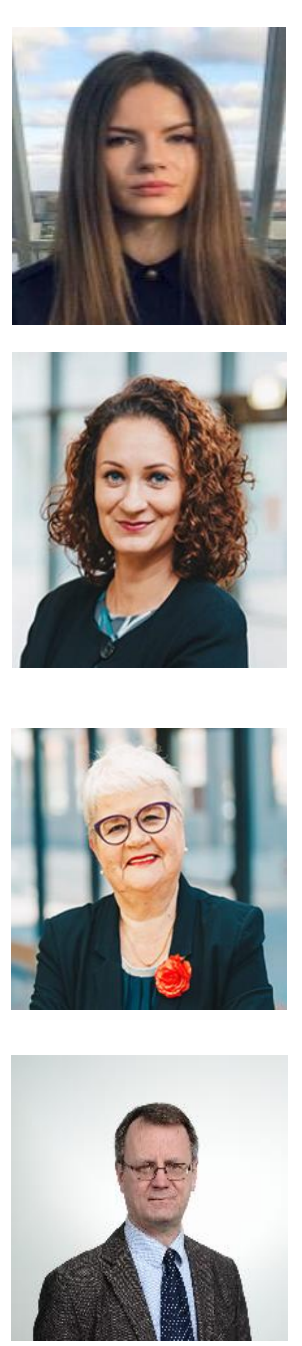

ORCID iD: https://orcid.org/0000-0003-3799-8647

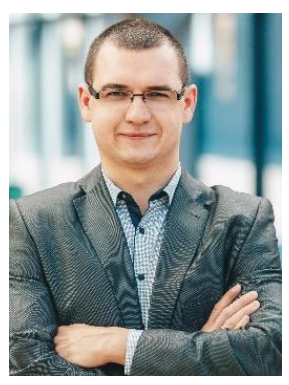

Vladimirs Kirsanovs, Dr. sc. ing. RTU IESE senior researcher defended his thesis in 2018 and received his doctorate in Environmental Engineering. He is working at Riga Technical University in the Institute of Energy Systems and Environment since 2011. The main research areas are connected with renewable energy technologies, biomass conversion technologies, energy system sustainability, flexibility and energy efficiency, sustainable transport. Vladimirs Kirsanovs has participated in more than 10 national and international scientific projects related to energy and environment. He is head of combustion research laboratory. He is a co-author of 26 scientific articles that are indexed in SCOPUS database, 2 monographs and 2 patents. Scientific articles are quoted 99 times and the h-index is 6. During the research, he has developed and applied 3 patent applications and co-authored 4 monographs.

E-mail: vladimris.kirsanovs@rtu.lv

ORCID iD: https://orcid.org/0000-0003-2501-5471 
Agita Gancone, M. Sc. geogr. She received the M. Sc. geogr. degree in the University of Latvia, Faculty of Geography and Earth Sciences in 2002. She is PhD student in Riga Technical University. She is working at Ministry of Environmental Protection and Regional Development as senior expert in the field of GHG inventory preparation and coordination, GHG emission mitigation. The main research areas are connected with GHG emission calculation, mitigation and projections in different sectors including agriculture, evaluation of agriculture ecoefficiency, biogas production.

E-mail: agancone@inbox.lv 